Економічні науки: збірник наукових праць Луцького національного технічного університету. Серія "Регіональна економіка". Випуск 18 (71). Редкол.: відп. ред. д.е.н., професор Л.Л. Ковальська. Луиьк: ІВВ Луиького НТУ, 2021. 278 с.

УДК 331.55

Шубала I.В., к.е.н., доцент

Мисковець O.I.

Луцький національний технічний університет

\title{
АНАЛІЗ ТА ОЦІНКА ЗАКОНОМІРНОСТЕЙ ЗМІНИ ПОКАЗНИКА РОБОЧОЇ СИЛИ У РЕГІОНІ
}

Метою дослідження є проведення аналізу та оцінки закономірностей зміни показника робочої сили на прикладі Волинської області як прикордонного регіону. Зроблено висновок, що існують резерви зростання робочої сили за рахунок зменшення чисельності осіб, які не знають де і як шукати роботу, зневірених, тих, які вважають, що немає підходящої роботи, працюють на сезонних роботах.

Ключові слова: робоча сила, зайняте населення, безробітне населення, особи, які не входять до складу робочої сили, лінія тренду, Волинська область.

\section{Shubala I.V., Myskovets O.I. \\ THE ESSENCE, COMPONENTS AND FACTORS OF FORMATION OF HUMAN RESOURCES OF THE ENTERPRISE}

The labor force is the basis of the labor potential of the country and individual regions. Therefore, it is important to constantly monitor changes in this indicator, study the causes and predict the prospects for change. The purpose of the study is to analyze and assess the patterns of change in the labor force on the example of Volyn region as a border region. The total population aged 15-70 years during the analyzed period was virtually unchanged -750 thousand people. Analysis of changes in the labor force showed that there was a sharp decline from 383.6 thousand people in 2013 to 455.4 thousand people in 2014, or 28.2 thousand people, or $5.8 \%$. Gradually, the number of labor force decreased in 2020 to the minimum level for the analyzed period - 416.0 thousand people, or decreased by 67.6 thousand people by 2013. Thus, the negative trend of declining labor force in the Volyn region during the period 2013-2020, especially in 2014, is associated with the influence of a number of factors that determined the change in the labor potential of the region as a whole. On the one hand, the tendency to decrease the employed population had a negative impact, especially in 2014 , which was associated with a decrease in economic activity of economic entities in the region and the country as a whole due to change of government, annexation of Crimea, war in Donbass, mobilization of resources to maintain the country's defense capabilities, which negatively affected the labor market. The change in the labor force and the 
Економічні науки: збірник наукових праць Луцького національного технічного університету. Серія "Регіональна економіка". Випуск 18 (71). Редкол.: відп. ред. д.е.н., професор Л.Л. Ковальська. Луцьк: ІВВ Луцького НТУ, 2021. 278 с.

intensification of labor migration processes to the EU countries also had a negative impact.

On the other hand, there was a flow of part of the population that was part of the labor force, in the group of economically inactive, ie those who do not belong to the labor force. This was mainly due to a sharp increase in the number of retirees in 2014 , as processes began to implement the pension reform, which provided for an increase in retirement age, length of service, restrictions on pensions and more. This has become a catalyst for the growth of this indicator. Also, mainly due to the decrease in the employed population, there was an increase in the number of mobilized persons for a special period, as well as persons who went to military service under contract. Reserves for labor growth have been identified by reducing the number of people who do not know where and how to look for work, the desperate, those who believe that there is no suitable job, work in seasonal jobs, the total value of which is estimated at 4.6 thousand people, and completion war in the Donbass will increase this figure to at least 10 thousand people.

Key words: labor force, employed population, unemployed population, persons who are not part of the labor force, trend line, Volyn region.

\section{Шубалая И.В., Мысковец О.И.}

\section{АНАЛИЗ И ОЦЕНКА ЗАКОНОМЕРНОСТЕЙ ИЗМЕНЕНИЯ ПОКАЗАТЕЛЯ РАБОЧЕЙ СИЛЫ В РЕГИОНЕ}

Целью исследования является анализ и оценка закономерностей изменения показателя рабочей силы на примере Волынской области как приграничного региона. Сделан вывод, что существуют резервы роста рабочей силы за счет уменьшения численности лиц, не знающих где и как искать работу, отчаявшихся, считающих, что нет подходящей работы, работающих на сезонных работах.

Ключевые слова: рабочая сила, занятое население, безработное население, лица, не входящие в состав рабочей силы, линия тренда, Волынская область.

Постановка проблеми у загальному вигляді і її зв'язок 3 важливими науковими та практичними завданнями. Загальновідомо, що робоча сила становить основу трудового потенціалу країни та окремих регіонів. Тому важливо постійно моніторити зміну цього показника, вивчати причини та прогнозувати перспективи зміни. Особливо важливо аналізувати та оцінювати зміну робочої сили у прикордонних регіонах, до яких відноситься і Волинська область, адже тут є альтернативи 
Економічні науки: збірник наукових праць Луцького національного технічного університету. Серія "Регіональна економіка". Випуск 18 (71). Редкол.: відп. ред. д.е.н., професор Л.Л. Ковальська. Луиьк: ІВВ Луиького НТУ, 2021. 278 с.

трудової міграції до більш розвинених країн $Є С$, які пропонують у кілька разів вищий рівень оплати праці.

Аналіз останніх досліджень, у яких започатковано вирішення проблеми. Вивченням тенденцій і закономірностей зміни робочої сили, зокрема на регіональному рівні, займалися багато вітчизняних вчених [1-5]. Але, ситуація на ринку праці постійно змінюється, а також змінною $є$ і сукупність факторів впливу на кількісні параметри робочої сили, тому виникає необхідність вивчення цих процесів, враховуючи поточні умови функціонування економіки окремого регіону та країни в цілому, особливо в умовах тотальних зовнішніх загроз.

Цілі статті. Метою даного дослідження $є$ проведення аналізу та оцінки закономірностей зміни показника робочої сили на прикладі Волинської області як прикордонного регіону.

Виклад основного матеріалу дослідження 3 повним обгрунтуванням отриманих наукових результатів. Поняття «робоча сила» постійно вживалося і продовжує вживатися в наукових дослідженнях, які стосуються вивчення трудового потенціалу країни та іiі окремих регіонів. В офіційній вітчизняній статистиці це поняття з'явилося відносно недавно.

Адже, до 2019 року під показником робоча сила розуміли економічно активне населення, але до розрахунку та подальшого аналізу бралося населення вікової групи 15-70 років. 32019 року згідно методологічних пояснень Державної служби статистики України надається таке визначення поняття «робоча сила» - «це населення обох статей віком 15 років і старше, яке впродовж обстежуваного тижня забезпечувало пропозицію робочої сили на ринку праці. Зайняті та безробітні в сумі складають робочу силу. Особи, які не входять до складу робочої сили (до 2019 року - економічно неактивне населення) - особи віком 15 років і старше, які впродовж обстежуваного тижня не відносилися ні до зайнятого, ні до безробітного населення» [6;9].

На початковому етапі аналізу доцільно проаналізувати зміну показника робочої сили у віці $15-70$ років на фоні 
Економічні науки: збірник наукових праць Луцького національного технічного університету. Серія "Регіональна економіка". Випуск 18 (71). Редкол.: відп. ред. д.е.н., професор Л.Л. Ковальська. Луцьк: ІВВ Луцького НТУ, 2021. 278 с.

загальної зміни чисельності населення цього віку за період 2013-2020 рр. (рис. 1).

Цей період цікавий тим, що 2013 рік характеризувався відносною стабільністю економіки нашої країни та регіонів, а наступні, враховуючи початок війни на Сході України та анексію Криму, були нестабільними, що відповідно мало вплив і на зміну динаміки робочої сили.

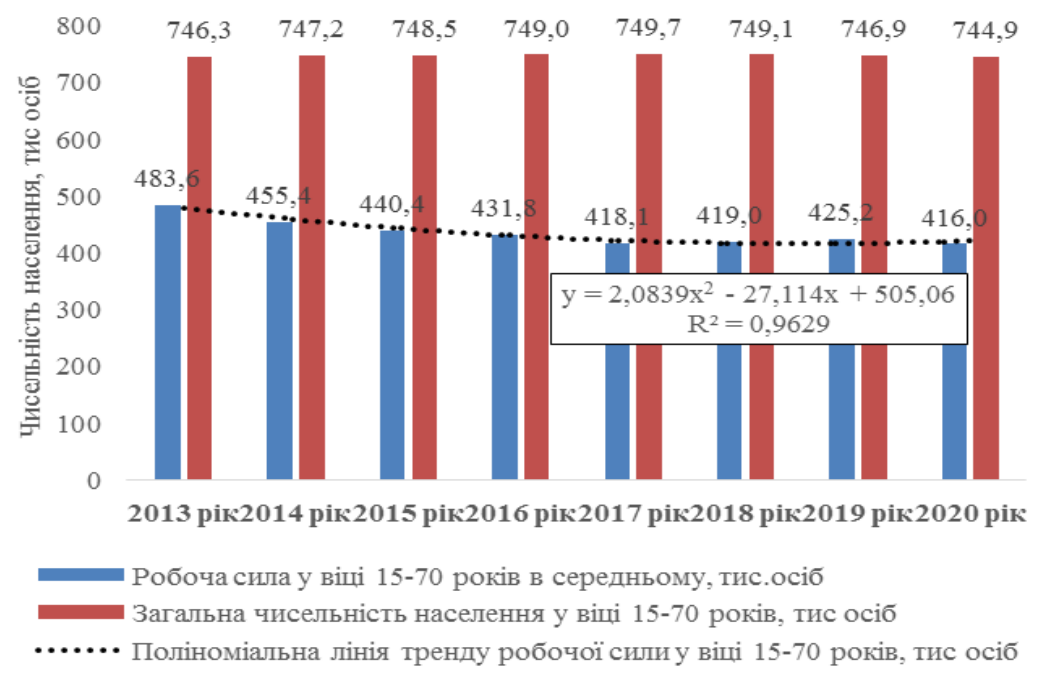

Рис. 1. Динаміка робочої сили у Волинській області за 2013-2020 pp. (побудовано автором за даними [6-9])

Як видно з рисунку, загальна чисельність населення у віці 15-70 років протягом аналізованого періоду була практично незмінною, коливаючись у межах 745-750 тис осіб. При цьому, все ж спостерігалося певне зменшення цього показника в кінці періоду у 2020 році до найнижчого значення - 744,9 тис осіб.

Аналізуючи зміну показника робочої сили, бачимо, що спостерігається його різке зниження з 383,6 тис осіб у 2013 році до 455,4 тис осіб у 2014 році, або на 28,2 тис осіб, тобто на 5,8\%. Надалі ця тенденція мала продовження і поступово чисельність 
Економічні науки: збірник наукових праць Луцького національного технічного університету. Серія "Регіональна економіка". Випуск 18 (71). Редкол.: відп. ред. д.е.н., професор Л.Л. Ковальська. Луцьк: ІВВ Луцького НТУ, 2021. 278 с.

робочої сили зменшилася у 2020 році до мінімального рівня за аналізований період - 416,0 тис осіб, або зменшилася на 67,6 тис осіб, або на 14,0\% до 2013 року.

Значною мірою таку негативну зміну можна пояснити економічною нестабільністю в країні після 2014 року, але щоб виявити першопричини таких змін доцільно надалі проаналізувати тенденції зміни основних складових робочої сили - чисельності зайнятого та безробітного населення, а також чисельності осіб, які не входять до складу робочої сили у Волинській області за аналогічний період (рис. 2).

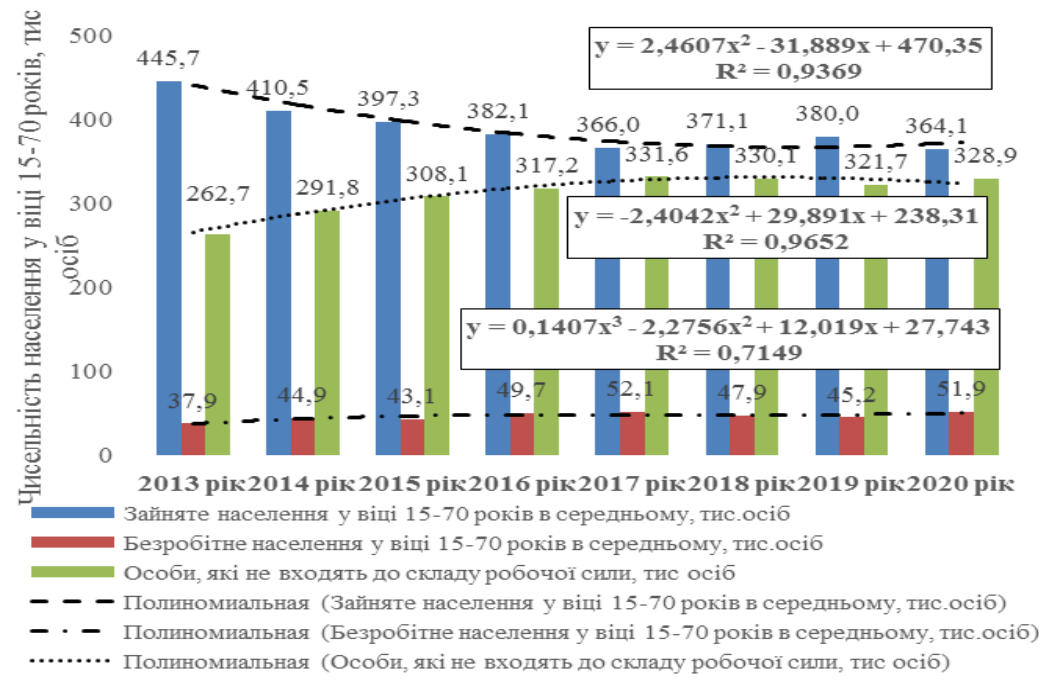

Рис. 2. Порівняння динаміки чисельності зайнятого, безробітного населення і осіб, які не входять до складу робочої сили у віці 15-70 рокі у Волинській області за 2013-2020 pp. (побудовано автором за даними [6-9])

3 рисунка видно, що найбільш характерною протягом аналізованого періоду $€$ негативна тенденція до постійного зменшення чисельності зайнятого населення - 3445,7 до 364,1 тис осіб, або на 81,6 тис осіб, 18,3\%. Дана тенденція може 
Економічні науки: збірник наукових праць Луцького національного технічного університету. Серія "Регіональна економіка". Випуск 18 (71). Редкол.: відп. ред. д.е.н., професор Л.Л. Ковальська. Луиьк: ІВВ Луиького НТУ, 2021. 278 с.

бути найкращим чином описана у вигляді поліноміальної трендової моделі, обраної на основі найбільшого значення коефіцієнта детермінації $\left(\mathrm{R}^{2}=0,9369\right)$.

Натомість відбувалося незначне зростання протягом цього періоду показника чисельності безробітного населення - 3 37,9 до 51,9 тис осіб, або 14,0 тис осіб, що становить 36,9\%. Але найкраща за значенням коефіцієнта детермінації $\left(\mathrm{R}^{2}=0,7149\right)$ трендова модель у вигляді поліноміальної залежності 3-го ступеня, свідчить про більш пологішу тенденцію до зростання безробітного населення. Тобто цей показник не $є$ основним, що визначав зміну робочої сили у регіоні.

3 іншого боку, аналізуючи зміну показника чисельності осіб, які не входять до складу робочої сили, спостерігаємо протилежну до чисельності зайнятих тенденцію до зростання - 3 262,7 до 328,9 тис осіб, або на 66,2 тис осіб, 25,2\% за увесь досліджуваний період. Побудована трендова модель, яка найкращим чином за достатньо високим максимальним значенням коефіцієнта детермінації $\left(\mathrm{R}^{2}=0,9652\right)$ у вигляді поліномінальної моделі 2-го ступеня підтверджує різку тенденцію до зростання даного показника, особливо у 2014-2017 pр., коли цей показник зростав. Але у наступних роках не спостерігалося стабільної тенденції до зростання.

Тобто на основі побудованих трендових моделей бачимо, що основними причинами зменшення чисельності робочої сили стало зменшення чисельності зайнятого населення, а також зростання чисельності осіб, які не відносяться до робочої сили.

Щодо зменшення чисельності зайнятого населення, то причини іiі зменшення пов'язуються 3 нестабільністю національної та регіональної економіки, яка функціонує в умовах продовження воєнних дій, а також засилля імпорту товарів, низьких доходів населення, відсутності дієвих стимулів до зростання доданої вартості у виробничій сфері. 3 іншого боку, потребують додаткового вивчення причини збільшення показника осіб, які не входять до складу робочої сили.

До чисельності осіб, які не входять до складу робочої сили (до 2019 року - економічно неактивного населення) відносять 
Економічні науки: збірник наукових праць Луцького національного технічного університету. Серія "Регіональна економіка". Випуск 18 (71). Редкол.: відп. ред. д.е.н., професор Л.Л. Ковальська. Луцьк: ІВВ Луцького НТУ, 2021. 278 с.

також осіб, які «не шукають роботу, до яких у свою чергу відноситься група осіб, які не бажають працювати, оскільки не мають необхідності. До цієї групи осіб відносяться: пенсіонери, студенти (учні) денної форми навчання, особи, які мають дохід від особистого селянського господарства, особи, які приступають до військової строкової служби, особи, які виконують домашні (сімейні) обов'язки, доглядають дітей, хворих; особи, які знаходяться на утриманні; особи, які оформляють пенсію; за станом здоров'я» [6;9].

Відповідно, надалі вивчено причини зміни чисельності осіб, які не входять до складу робочої сили за аналізований період, враховуючи необхідність детальнішого розгляду зміни за період 2013-2014 pр. (табл. 1).

Таблиця 1

Динаміка чисельності осіб, які не входять до складу робочої сили за причинами незайнятості у Волинській області за період 2013-2020 pp.

\begin{tabular}{|c|c|c|c|c|c|c|}
\hline \multirow{2}{*}{ Причини незайнятості } & \multirow{2}{*}{2013 рік } & \multirow{2}{*}{2014 рік } & \multirow{2}{*}{2020 рік } & \multicolumn{2}{|c|}{$\begin{array}{c}\text { Абсолютний приріст, } \\
\text { тис осіб } \\
\end{array}$} & \multirow{2}{*}{$\begin{array}{l}\text { Темп росту } \\
\text { 2020p. до } \\
\text { 2013p., \% }\end{array}$} \\
\hline & & & & $\begin{array}{l}\text { 2014p. до } \\
\text { 2013p. }\end{array}$ & $\begin{array}{l}\text { 2020p. до } \\
\text { 2014p. }\end{array}$ & \\
\hline пенсіонери & 115,6 & 133,4 & 163,8 & 17,8 & 30,4 & 141,7 \\
\hline $\begin{array}{l}\text { учні, студенти денної форми } \\
\text { навчання }\end{array}$ & 65,4 & 61,0 & 67,8 & $-4,4$ & 6,8 & 103,6 \\
\hline $\begin{array}{l}\text { виконують домашні (сімейні) } \\
\text { обов'язки }\end{array}$ & 71,2 & 70,6 & 71,4 & $-0,6$ & 0,8 & 100,3 \\
\hline стан здоров'я & 2,4 & 2,6 & 2,0 & 0,3 & $-0,7$ & 83,5 \\
\hline зневірені & 0,8 & 2,6 & 1,0 & 1,8 & $-1,6$ & 125,2 \\
\hline перебувають на угриманні & 0,5 & 0,0 & 0,0 & $-0,5$ & 0,0 & 0,0 \\
\hline $\begin{array}{l}\text { не знають де і як шукати } \\
\text { роботу }\end{array}$ & 1,8 & 4,4 & 0,7 & 2,5 & $-3,7$ & 35,8 \\
\hline \begin{tabular}{|lcc} 
вважають, & що & немає \\
підходящої роботи & \\
\end{tabular} & 2,1 & 8,2 & 2,6 & 6,1 & $-5,5$ & 125,2 \\
\hline сезонний характер роботи & 0,8 & 5,3 & 0,3 & 4,5 & $-4,9$ & 41,7 \\
\hline $\begin{array}{l}\text { сподіваються повернутися на } \\
\text { попередню роботу }\end{array}$ & 0,0 & 0,3 & 0,0 & 0,3 & $-0,3$ & 0,0 \\
\hline інші & 2,1 & 3,5 & 19,4 & 1,4 & 15,9 & 923,3 \\
\hline Всього & 262,7 & 291,8 & 328,9 & 29,1 & 37,1 & 125,2 \\
\hline
\end{tabular}

Примітка. Побудовано авторами на основі даних [7-9]. 
Економічні науки: збірник наукових праць Луцького національного технічного університету. Серія "Регіональна економіка". Випуск 18 (71). Редкол.: відп. ред. д.е.н., професор Л.Л. Ковальська. Луиьк: ІВВ Луиького НТУ, 2021. 278 с.

Як видно з таблиці, близько половини чисельності осіб, які не входять до складу робочої сили припадає на чисельність пенсіонерів. Також найбільшій частки 20-25\% займають учні, студенти денної форми навчання, а також особи, які виконують домашні (сімейні) обов'язки. Частка та чисельність інших категорій осіб, які не входять до складу робочої сили були значно меншими.

Детальніше аналізуючи ці зміни, можна констатувати, що основною причиною зростання чисельності осіб, які не входять до складу робочої сили у 2013-2014 рр. на 29,1 тис осіб було зростання чисельності пенсіонерів - 3 115,6 до 133,4 тис осіб, або на 17,8 тис осіб, тобто $15,4 \%$. Також, у зв'язку зі складною економічною ситуацією у 2014 році, відбувся приріст чисельності осіб, які вважали, що немає підходящої роботи (+6,1 тис осіб), осіб, які не знали, де і як шукати роботу (+2,5 тис осіб), а також осіб, які мали сезонний характер роботи (+4,5 тис осіб). Але паралельно зменшилася на 4,4 тис осіб чисельність учні, студенти денної форми навчання, що пов'язується з демографічною кризою попередніх років.

Надалі у наступних роках вказана тенденція до зростання чисельності пенсіонерів знайшла продовження, адже цей показник збільшився за період 2014-2020 рр. ще на 30,4 тис осіб. Натомість вже спостерігалася тенденція до зростання чисельності учнів, студентів денної форми навчання (на 6,8 тис осіб), а також інших категорій (на 15,9 тис осіб). Можна припустити, що зростання чисельності інших категорій осіб пов'язується із військовою мобілізацією частини населення у зв'язку із необхідністю підтримувати обороноздатність нашої країни на Сході під час війни на Донбасі. Хоча офіційні статистичні дані про такі мобілізаційні заходи недоступні.

Таким чином чисельність осіб, які не відносяться до робочої сили у 2014-2020 рр. зросла ще на 37,1 тис осіб, а в цілому за період - на 66,2 тис осіб, або 25,2\%. При цьому, найбільшим темпом росту характеризувалася саме категорія інших осіб (зросла у 9,3 рази), а також категорія пенсіонерів (на 
Економічні науки: збірник наукових праць Луцького національного технічного університету. Серія "Регіональна економіка". Випуск 18 (71). Редкол.: відп. ред. д.е.н., професор Л.Л. Ковальська. Луиьк: ІВВ Луцьького НТУ, 2021. 278 с.

41,7\%), зневірених та тих, що вважають, що немає підходящої роботи (на 25,2\%).

Висновки. Отже, негативна тенденція до зменшення чисельності робочої сили у Волинській області протягом періоду 2013-2020 рр., особливо у 2014 році, пов'язується 3 впливом ряду факторів, які визначали зміну трудового потенціалу регіону загалом.

3 одного боку, негативний вплив мала стала тенденція до зменшення чисельності зайнятого населення, особливо у 2014 році, що була пов'язана із зменшенням економічної активності суб' єктів господарювання у регіоні та країні в цілому через зміну влади, анексію Криму, початок війни на Донбасі, мобілізацію ресурсів на підтримання обороноздатності країни, що негативно вплинуло на ринок праці. Також негативно вплинула на зміну робочої сили і активізація процесів трудової міграції до країн ЄС.

3 іншого боку, відбувся перетік частини населення, що входило до складу робочої сили, в групу економічно неактивних, тобто тих, які не належать до робочої сили. Головним чином це відбулося через різке збільшення кількості пенсіонерів у 2014 році, адже розпочалися процеси щодо впровадження пенсійної реформи, що передбачала збільшення пенсійного віку, страхового стажу, встановлення обмежень на розмір пенсії тощо. Це стало певним каталізатором зростання цього показника. Також переважно за рахунок зменшення зайнятого населення відбулося зростання чисельності мобілізованих осіб на період особливого періоду, а також осіб, які пішли на військову службу за контрактом.

Разом $з$ тим, існують резерви зростання робочої сили за рахунок зменшення чисельності осіб, які не знають де і як шукати роботу, зневірених, тих, які вважають, що немає підходящої роботи, працюють на сезонних роботах, загальна величина яких оцінюється у 4,6 тис осіб, а завершення війни на Донбасі дозволить збільшити цей показник ще принаймні до 10 тис осіб. 
Економічні науки: збірник наукових праць Луцького національного технічного університету. Серія "Регіональна економіка". Випуск 18 (71). Редкол.: відп. ред. д.е.н., професор Л.Л. Ковальська. Луиьк: ІВВ Луиького НТУ, 2021. 278 с.

\section{Список бібліографічного опису}

1. Shubalyi O., Rud N., Shubala I., Gordiichuk A., Potomkina O., Kosinskyi P. Assessment of economic activity of the rural population by age and gender groups: a case study of Ukraine. Scientific Papers Series "Management, Economic Engineering in Agriculture and Rural Development". 2021. Vol. 21(2). P. 555-568.

2. Гордійчук А.І., Копера К.П. Шляхи регулювання мобільності робочої сили в Україні. Економічні науки. Серія : Економічна теорія та економічна історія. 2019. Вип. 16. С. 33-41.

3. Дзямулич М.І., Потьомкіна О. В. Механізми та важелі регулювання професійної мобільності робочої сили. Економічний форум. 2018. № 4. С. 303309.

4. Ткаченко Л.Г. Розширення аналітичних можливостей обстеження робочої сили. Статистика України. 2019. № 4. С. 14-20.

5. Шубалий О.М., Шубала І.В., Потьомкіна О.В. Моніторинг регіонального ринку праці: тендениії, закономірності, прогнози. М-во освіти і науки України; Луцький НТУ. Луцьк: IBВ Луцького НТУ, 2018. 220 с.

6. Головне управління статистики у Волинській області : офіційний веб-сайт: URL: http://www.lutsk.ukrstat.gov.ua.

7. Економічна активність населення України 2013. Статистичний збірник. Державна служба статистики України. К., 2014. 197 с.

8. Економічна активність населення України 2014. Статистичний збірник. Державна служба статистики України. К., 2015. 207 с.

9. Робоча сила України 2020. Статистичний збірник. Державна служба статистики України. К., 2021. 190 с.

\section{References}

1. Shubalyi O., Rud N., Shubala I., Gordiichuk A., Potomkina O., Kosinskyi P. (2021). Assessment of economic activity of the rural population by age and gender groups: a case study of Ukraine. Scientific Papers Series "Management, Economic Engineering in Agriculture and Rural Development”. 21(2). 555-568.

2. Gordiychuk A.I., Kopera K.P. (2019). hlyakhy rehulyuvannya mobil'nosti robochoyi syly $\mathrm{v}$ Ukrayini [Ways to regulate labor mobility in Ukraine]. Ekonomichni nauky. Seriya : Ekonomichna teoriya ta ekonomichna istoriya [Economic sciences. Series: Economic theory and economic history]. 16, 33-41.

3. Dzyamulich M.I., Potemkina O.V. (2018). Mekhanizmy ta vazheli rehulyuvannya profesiynoyi mobil'nosti robochoyi syly [Mechanisms and levers of regulation of professional mobility of labor]. Ekonomichnyy forum [Economic forum]. № 4, 303-309.

4. Tkachenko L.G. (2019). Rozshyrennya analitychnykh mozhlyvostey obstezhennya robochoyi syly [Expanding the analytical capabilities of the labor force survey]. Statystyka Ukrayiny [Statistics of Ukraine]. № 4, 14-20.

5. Shubalyi O.M., Shubala I.V, Potemkina O.V. (2018). Monitorynh rehional'noho rynku pratsi: tendentsiyi, zakonomirnosti, prohnozy [Monitoring of 
Економічні науки: збірник наукових праць Луцького національного технічного університету. Серія "Регіональна економіка". Випуск 18 (71). Редкол.: відп. ред. д.е.н., професор Л.Л. Ковальська. Луцьк: ІВВ Луцького НТУ, 2021. 278 с.

the regional labor market: trends, patterns, forecasts]. Lutsk: IVV Lutsk NTU, $220 \mathrm{p}$.

6. Holovne upravlinnya statystyky u Volyns'kiy oblasti: ofitsiynyy veb-sayt [Main Department of Statistics in the Volyn region. Official website]. Retrieved from http://www.lutsk.ukrstat.gov.ua. [in Ukrainian].

7. Economic activity of the population of Ukraine 2013 (2014). Statistical collection. State Statistics Service of Ukraine. Kyiv, 197 p. [in Ukrainian].

8. Economic activity of the population of Ukraine 2014 (2015). Statistical collection. State Statistics Service of Ukraine. Kyiv, 207 p. [in Ukrainian].

9. Labor force of Ukraine 2020 (2021). Statistical collection. State Statistics Service of Ukraine. Kyiv, $190 \mathrm{p}$.

DOI: $\underline{\text { https://doi.org/10.36910/2707-6296-2021-18(71)-27 }}$

УДК 658.14 (477.8): 332.14

Шубалий О.М., д.е.н., професор

Гриник I.C., аспірант кафедри економіки

Луцький національний технічний університет

\section{ОЦІНКА ФІНАНСОВОГО ЗАБЕЗПЕЧЕННЯ СТАЛОГО РОЗВИТКУ ПІВНІЧНО-ЗАХІДНОГО РЕГІОНУ ЗА РАХУНОК КОШТІВ ЗВЕДЕНИХ МІСЦЕВИХ БЮДЖЕТІВ}

Мета дослідження полягає в проведенні оцінки фінансового забезпечення сталого розвитку Північно-Західного регіону за рахунок коштів зведених місцевих бюджетів. Проведено порівняльний аналіз доходів та рівня самодостатності зведених місцевих бюджетів Волинської та Рівненської областей; порівняльний аналіз динаміки показника валового регіонального продукту, що припадає в середньому на 1 грн загальних видатків місцевих бюджетів; вивчено зміну питомої ваги статей видатків зведених місцевих бюджетів, а також вивчено динаміку показників фінансової стійкості зведених місцевих бюджетів Північно-Західного регіону.

Ключові слова: місцеві бюджети, фінансове забезпечення, сталий розвиток, зведені доходи та видатки бюджету, Північно-Західний регіон. 